\begin{tabular}{|c|c|c|}
\hline $\begin{array}{l}\text { FATIH } \\
\text { SULTAN } \\
\text { MEHMET } \\
\text { VAKK UNIIVERSIESI } \\
2010\end{array}$ & $\begin{array}{l}\text { FSM İlmî Araştırmalar Insan ve Toplum Bilimleri Dergisi } \\
\text { FSM Scholarly Studies Journal of Humanities and Social Sciences } \\
\text { Sayı/Number } 15 \text { Yıl/Year } 2020 \text { Bahar/Spring } \\
\text { (C2020 Fatih Sultan Mehmet Vakıf Üniversitesi }\end{array}$ & 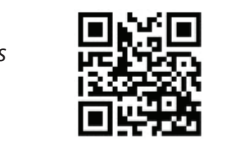 \\
\hline DOI: & http://dergipark.org.tr/fsmia & http://dergi.fsm.edu.tr \\
\hline Araştırma Makalesi / Research Article & Geliş Tarihi / Received: 01.05.2020 Kabul Tarihi / Accepted: 12.06.2020 & FSMIAD, 2020; (15): 431-458 \\
\hline
\end{tabular}

\title{
Yurtta Kalan Üniversite Öğrencilerinin Anksiyete, Sosyal Destek ve Yaşam Doyum Düzeyleri İle Baş Etme Stillerinin İncelenmesi ${ }^{*}$
}

\author{
Zahide Tepeli Temiz ${ }^{* \star}$ \\ Vahide Ulusoy Gökçek ${ }^{* \star}$
}

\section{$\ddot{O} z$}

Kişinin ailesi, arkadaşları veya önem verdiği insanlardan aldığı destek, strese karş1 önemli bir koruyucu mekanizmadır. Koruyucu faktörleri tanımlamaya yönelik çalışmalar, sosyal destek ve baş etme stratejilerinin kaygıyı azaltmaya yardımcı süreçler olduğuna dikkat çekmektedir. Bu çalışmanın temel amacı, yurtta yaşayan üniversite öğrencilerinin algıladıkları sosyal desteğin ve baş etme stratejilerinin diğer öğrencilerden farkl1laşıp farklılaşmadığını incelemektir. Ayrıca bu çalışmada üniversite öğrencilerinin yaşamdan aldıkları doyumu ve anksiyete düzeylerini yordayan değişkenlerin incelenmesi amaçlanmaktadır. Örneklem grubu 206 (kadın=89, erkek=116) üniversite öğrencisinden oluşmaktadır. Katılımcılara Stresle Başa Çıkma Ölçeği, Algılanan Sosyal Destek Ölçeği,

** Bu çalışma 2-5 Temmuz 2019 tarihinde Moskova'da IX. European Congress of Psychology kongresinde sözlü bildiri olarak sunulmuştur.

** Sorumlu Yazar, Arş. Gör., Fatih Sultan Mehmet Vakıf Üniversitesi Psikoloji Bölümü İstanbul/ Türkiye, ztemiz@fsm.edu.tr, orcid.org/0000-0001-6980-1226

*** Öğr. Gör., İstinye Üniversitesi Psikoloji Bölümü, İstanbul/Türkiye, vahide.gokcek@istinye. edu.tr, orcid.org/0000-0001-8787-9510 
Yaşam Doyumu Ölçeği ve Beck Anksiyete Envanteri uygulanmıştır. Araştırmanın bulguları yurtta kalan öğrencilerin sosyal destek düzeylerinin diğerlerinden farklılaşmadığını göstermektedir. Baş etme stillerindeki farklılığa bakıldığında ise ailesiyle yaşayan katılımcıların yurtta yaşayan üniversite öğrencilerinden daha fazla kendine güvenli baş etme stili kullandıkları görülmektedir. Hiyerarşik regresyon analizi sonuçları, cinsiyet, çaresiz ve kendine güvenli baş etme stratejileri, algılanan sosyal destek ve anksiyete puanlarının yaşam doyumu üzerinde anlamlı bir katkı sağladığını göstermektedir. Genç yetişkinlerin anksiyete puanlarını ise baş etme stratejileri ve yaşamdan aldıkları doyum etkiliyor görünmektedir. Baş etme stratejilerini geliştirmeye yönelik yapılacak destekleyici çalışmaların öznel iyi oluşu artırabileceği ve kaygıyı azaltabileceği düşünülmektedir.

Anahtar Kelimeler: Anksiyete, baş etme, sosyal destek, yaşam doyumu, yurt yaşamı.

\title{
A Study on the Anxiety, Social Support, Life Satisfaction Levels, and Coping Strategies Among University Students in Dormitories
}

\begin{abstract}
The support of the family, friends and the people one cares about are most important protective coping factors with stress. Studies on protective factors highlight that social support and coping are processes helping to reduce anxiety. The main objective of the current study is to investigate whether the perceived social support and coping strategies of students who are living in dormitories differ from other students. Another aim of the study was to examine the predictors of the satisfaction and anxiety levels of the groups. The sample comprised 206 university students ( $\mathrm{N}=89$ women, 116 men. Ways of coping Inventory, MSPSS, Satisfaction with Life Scale and Beck Anxiety Inventory are used in gathering the data. The findings of the study show that dormitory life provides social support to students. When the differences in coping styles are examined, it is seen that the participants living with their families use self-confident coping style more than the students living in dormitories do. The results of the hierarchical regression analysis indicate that gender, helpless and self-confident coping strategies, perceived social support and anxiety scores made significant contributions to variance in life satisfaction scores. Anxiety scores of young adults seem to be influenced by coping strategies and satisfaction with life. It is thought that supportive studies to develop coping strategies may increase subjective well-being and decrease anxiety level.
\end{abstract}

Keywords: Anxiety, coping, dormitory life, life satisfaction, social support. 


\section{Giriş}

Hızla büyüyen Türk toplumunda genç nüfusun üniversitede okuma oranları da son on yılda hızlı bir artış göstermektedir. Büyük şehirlerdeki üniversitelere olan yoğun talep ise yurtlar, öğrenci evleri gibi pek çok konaklama alternatifini beraberinde getirmektedir. Yeni yaşam biçimi, sosyal destek mekanizmasının çerçevesini de genişletmektedir. Öğrencilerin sosyal destek mekanizmalarını ne kadar sürdürebildikleri ve sürece ne kadar uyum gösterdikleri araştırmacıların merak ettikleri konulardan birini oluşturmaktadır ${ }^{12}$. Öğrencilerle yapılan çalışmalar, algilanan sosyal desteğin üniversiteye uyum sürecinde önemli rol oynadığını ortaya koymaktadır ${ }^{345}$. Çevreden (aile, arkadaşlar, akraba) alınan sosyal desteğin değişmesi ise strese yol açabilecek etmenlerden biri olarak değerlendirilmektedir ${ }^{67}$. Bununla beraber kişinin başa çıkma yolları, yeni çevre koşullarına uyum sağlamasını şekillendirmektedir ${ }^{8}$.

Stres modern toplumun kaçınılmaz bir olgusudur. Yaşamın farklı zamanlarında ve farklı alanlarında ortaya çıkan stresin kaynağı doğru bir şekilde tanımlandığında stresi kontrol etmeye yönelik stratejiler geliştirmek de mümkün olmaktadır ${ }^{9}$. Genel stres modeli, kişinin baş etme kaynaklarının sınırlarını aşan stresin

1 Laura J. Friedlander - Graham J. Reid - Naomi Shupak - Robert Cribbie, "Social support, self-esteem, and stress as predictors of adjustment to university among first-year undergraduates”, Journal of College Student Development, cilt 48, say1 3, 2007, s. 259-274.

2 Agnes Szabo - Colleen Ward - Paul E. Jose, "Uprooting stress, coping, and anxiety: A longitudinal study of international students”. International Journal of Stress Management, cilt 23, say1 2, 2016, s. 190-208.

3 Sheldon Cohen - Drury R. Sherrod - Margaret S. Clark, "Social skills and the stress-protective role of social support", Journal of Personality and Social Psychology, cilt 50, say1 5, 1986, s. 963-973.

4 Sheldon Cohen - Thomas A. Wills, "Stress, social support, and the buffering hypothesis", Psychological Bulletin, cilt 98, 1985, s. 310-357.

5 Laura J. Friedlander, a.g.e.

6 James Rankin - Courtney Paisley - Mazheruddin M. Mulla - Theodore S. Tomeny, "Unmet social support needs among college students: Relations between social support discrepancy and depressive and anxiety symptoms", Journal of Counseling Psychology, cilt 65, say1 4, 2018, s. 474-489.

7 Agnes Szabo, a.g.e.

8 Ingris K. Weigold - Christine Robitschek, "Agentic personality characteristics and coping: Their relation to trait anxiety in college students", American Journal of Orthopsychiatry, cilt 81, say1 2, 2011, s. 255-264.

9 Hatice Odacı - Özkan Çıkrıç̧ı, “University students' ways of coping with stress, life satisfaction and subjective well-being", TOJCE: The Online Journal of Counselling and Education, cilt 1 , say1 3, 2012, s. 118-131. 
olumsuz duygu duruma neden olduğunu ortaya koymaktadır ${ }^{10}$. Folkman ve Lazarus stresle baş etme stratejilerinin kişiyi olumsuz fiziksel ve psikolojik çıktılara karşı koruduğuna dikkat çekmektedir ${ }^{11}$. Kişinin sosyal çevresi, inanc1, değerleri ve amaçları gibi kişisel faktörler ise başa çıkma biçimlerini etkilemektedir.

Öznel iyi oluş olumlu ve olumsuz duygulanım boyutlarını içerisinde barındırmaktadır. Olumlu duygulanım mutluluk, neşe ve heyecan gibi duyguları içermektedir $^{12}$. Olumlu duygulanım bireyin yaşadığı neşe, mutluluk gibi duygularla diğer insanlara ve etkinliklere olumlu tepkilerini kapsamaktadır. Olumsuz duygulanım endişe, mutsuzluk, öfke ve üzüntü gibi duyguları içermektedir ${ }^{13}$. Olumsuz duygulanımın fazla olması bireyin öznel iyi oluşunun düşük olduğuna işaret etmektedir. Bu çalışmada öznel iyi oluşun olumlu göstergesi yaşam doyumu ile olumsuz göstergesi ise anksiyete belirtileri olarak ele alınmıştır.

\section{Koruyucu Faktörler: Sosyal Destek ve Baş Etme Stratejileri}

Psikolojik strese yol açan etmenleri inceleyen çalışmaların yanı sıra strese karşı koruyucu faktörleri tanımlamanın önemine vurgu yapan araştırmalar da bulunmaktadır. Bu çalışmalar, sosyal destek ve baş etme stratejilerinin kaygıyı azaltmaya yardımcı olabilecek süreçler olduğuna dikkat çekmektedir ${ }^{14}$.

Kişinin kendisine değer verildiği hissi ve destek verici bir çevrenin parçası olduğu algısı ile karakterize olan ${ }^{15}$ sosyal destek; duygusal ilgi, fiziksel yardım, bilgi ve değer gibi bireyler arasındaki karşılıklı etkileşimleri tanımlamaktadır ${ }^{16}$. Sosyal destek, kişiye stres anında çevresi tarafından sağlanan materyal ve psikolojik yardım olarak da tanımlanmaktadır. Kendisine değer verildiğini, sevildiğini, desteklendiğini ve önemsendiğini hisseden bireylerin fiziksel ve duygusal iyi oluşlarının daha yüksek olduğu, çevreleriyle daha iyi

10 Lisa Crockett - Maria I. Hurbide - Rosalie A.T. Stone - Meredith McGinley - Marcela Raffaelli - Gustavo Carlo, "Acculturative stress, social support, and coping: Relations to psychological adjustment among Mexican American college students", Cultural Diversity and Ethnic Minority Psychology, cilt 13, say1 4, 2007, s. 347-355.

11 Susan Folkman - Richard S. Lazarus, Stress, Appraisal, And Coping, New York, Springer Publishing Company, 1984.

12 Ed Diener - Marissa Diener, "Cross-cultural correlates of life satisfaction and self-esteem", E. Diener içinde, Culture and Well-Being, The Collected Works of Ed Diener, New York, Springer, 2009, s. s. 71-92.

13 a.g.e.

14 Lisa Crockett, a.g.e.

15 Shelley E. Taylor, "Social support: A review”, H. S. Friedman içinde, The Oxford Handbook of Health Psychology, Newyork, Oxford University Press, 2011, s. 189-214.

16 Sheldon Cohen, a.g.e. 
uyum gösterdikleri ve yaşamdan aldıkları doyumun daha yüksek olduğu öne sürülmektedir ${ }^{17}$.

Kişinin zor zamanlarında ailesi, arkadaşları veya önem verdiği insanlardan alabileceği fiziksel ve duygusal desteğe yönelik inanc1, strese karş1 önemli bir koruyucu mekanizmadır ${ }^{18}$. Daha fazla sosyal desteğe sahip olan insanların yaşam stresörleriyle daha iyi başa çıkma eğiliminde oldukları görülmüş ve stres verici durumla başa çıkmaya ihtiyaç duyulduğunda sosyal destek kaynaklarına ulaşılabileceğine yönelik algının ise psikolojik kaynakların kullanımını kolaylaştırdığg düşünülmektedir. Bu durum, kişinin stres verici durumları yeniden değerlendirmesini mümkün k1lmakta ve stresin negatif etkilerini (depresyon, anksiyete gibi) azaltmaktadır ${ }^{19}$.

Üniversite yaşamına geçiş önemli bir yaşam değişimi olarak nitelendirilmektedir. Bu yaşam değişimi genç yetişkinler için bir stres kaynağ 1 olabilmektedir ${ }^{20}$. Yeni sosyal ilişkiler, yeni yaşam koşulları, akademik beklentiler ve gelecek kaygısı üniversite öğrencilerinin stresle başa çıkma düzeylerini olumsuz etkileyebilmektedir ${ }^{21}$. Sosyal destek ise bu yaşam değişiminde koruyucu bir mekanizma olarak işlev görmektedir. Friedlander ve arkadaşlarının ${ }^{22}$ çalışması da sosyal desteğin üniversite öğrencilerinde koruyucu bir mekanizma olduğu teorisini desteklemektedir.

Önemli miktarda çalışma, pozitif sosyal desteğin faydalarına dikkat çekmektedir $^{23}$. Örneğin Clark ve arkadaşlar. ${ }^{24}$, algılanan sosyal desteği yüksek olan öğrencilerin daha az stres yaşadıklarını, Eker ve Arkar ${ }^{25}$ algılanan sosyal

17 James Rankin, a.g.e.

18 Karen S. Rook, "Social support versus companionship: effects on life stress, loneliness, and evaluations by others", Journal of Personality and Social Psychology, cilt 52, say1 6, 1987, s. 1132-1147.

19 Donice M. Banks - Carl F.Weems, "Family and peer social support and their links to psychological distress among hurricane-exposed minority youth", American Journal of Orthopsychiatry, cilt 84, say1 4, 2014, s. 341-352.

20 Sara B. Oswalt - Christina C. Riddock, "What do about being overwhelmed: Graduate students, stress and university services", The College Student-Affairs Journal, cilt 27, say1 1, 2007, s. $24-44$.

21 a.g.e.

22 Laura J. Friedlander, a.g.e.

23 James Rankin, a.g.e.

24 Heddy Kovach Clark - Nancy L. Murdock - Kristin Koetting, "Predicting burnout and career choice satisfaction in counseling psychology graduate students", The Counseling Psychologist, cilt 37, 2009, s. 580-606.

25 Doğan Eker - Haluk Arkar, "Çok boyutlu algılanan sosyal destek ölçeği' nin faktör yapısı, geçerlik ve güvenirliği”, Türk Psikoloji Dergisi, cilt 10, say1 34, 1995, s. 17-25. 
desteğin depresyon ve kaygı puanlarıyla negatif korelasyon gösterdiğini bulgulamışlardır. Diğer çalışmalar ise algılanan sosyal desteğin öznel iyi oluş ve akademik başarıyla ilişkili olduğunu ortaya koymuşlardır ${ }^{26}{ }^{27}$. Bununla beraber yurtta veya ailesiyle yaşayan öğrencilerin sosyal destek düzeylerini karşılaştıran çalışmalar bulunmamaktadır. Bu çalışmanın literatürdeki bu boşluğa önemli bir katkı sağlayacağı düşünülmektedir.

\section{Yaşam Doyumu ve Sosyal Destek}

Yaşam doyumu 'kişinin yaşamdan aldığı genel doyumun bilişsel değerlendirmesi' şeklinde tanımlanmaktadır ${ }^{28} 29$. Öznel iyi oluşun bir göstergesi olan yaşam doyumu bireyin, yaşamıyla ilgili bilişsel ve duygusal değerlendirmelerini içermektedir ${ }^{30}$. Yaşam doyumu ayrıca bireylerin mutluluğu, iyi oluşu, ruh sağlı̆̆ ve olumlu işlevselliğinin önemli göstergelerinden biridir ${ }^{31}{ }^{32}$. Öznel iyi oluşun kaynaklarını inceleyen çalışmalar, sosyal desteğin, arkadaş sayısının, güçlü romantik ilişkilerin, sosyal becerilerin, materyal kaynakların, sağlık ve fiziksel çekiciliğin öznel iyi oluşla ilişkili olduğunu ortaya koymaktadırlar (örn: Adams, King ve King, 1996; Aquino, Altmaier, Russell ve Cutrona, 1996; Diener ve Fujita, 1995; Kapıkıran, 2013). Psikolojik bir ihtiyaç olarak olarak sosyal desteğin karşılanması ise bireyin yaşamının diğer yönlerini de (mutlululuk, ruh sağllğı, öznel

26 Juyeon Song - Mimi Bong - Kyehyoung Lee - Sung-il Kim, "Longitudinal investigation into the role of perceived social support in adolescents' academic motivation and achievement", Journal of Educational Psychology, cilt 107, say1 3, 2005, s. 821-841.

27 Kelley A. Tompkins - Kierra Brecht - Brock Tucker - Joshua K. Swift - Lucia L. Neander, "Who matters most? the contribution of faculty, student-peers, and outside support in predicting graduate student satisfaction", Training and Education in Professional Psychology, cilt 10, say1 2, 2016, s. 102-108.

28 Wanfen Chen, et.al., "Perceived social support and self-esteem as mediators of the relationship between parental attachment and life satisfaction among Chinese adolescents", Personality and Individual Differences, cilt 108, 2017, s. 98-102.

29 Shengquan $\mathrm{Ye}$ - Lu Yu - Kin-Kit Li, "A cross-lagged model of self-esteem and life satisfaction: Gender differences among Chinese university students", Personality and Individual Differences, cilt 52, 2012, s. 546-551.

30 Ed Diener, a.g.e.

31 Bruce Headey - Jonathan Kelly - Alex Wearing, "Dimensions of mental health: life satisfaction, positive affect, anxiety and depression", Social Indicators Research, cilt 29, 1993, s. 63-82.

32 Carmel Proctor - P. Alex Linley, "Life Satisfaction in Youth", G. Fava ve C. R. (eds.) içinde, Increasing Psychological Well-being in Clinical and Educational Settings, Cross-Cultural Advancements in Positive Psychology, 2014, s. 199-215. 
iyi oluş, işlevsellik) şekillendirmektedir ${ }^{33}{ }^{34}$. Bu bağlamda Gayathri ve Karthikeyan'nın çalışması (2016) psikolojik iyilik hali ve yaşam doyumunun sosyal destek ile ilişkili olduğunu göstermektedir. Diener ve Fujita ${ }^{35}$, aile desteğinin ve yakın arkadaşların varlığı ile öznel iyi oluş, yaşam doyumu ve pozitif duygu durum arasında anlamlı bir ilişkinin varlığına dikkat çekmektedir. Tompkins ve arkadaşlarının üniversite öğrencileriyle yaptıkları çalışma ise, sosyal desteğin yaşam doyumu puanlarındaki varyansın \%30'unu açıkladığını göstermektedir ${ }^{36}$. Mahmoud ve arkadaşlarının ${ }^{37}$ yaptığ 1 çalışma ise yaşamdan daha az doyum alan üniversite öğrencilerinin daha fazla depresyon, anksiyete ve stres yaşadıklarını ortaya koymuştur.

\section{Baş Etme Stratejilerinin Anksiyete ve Yaşam Doyumu ile İlişkisi}

Klasik stres ve baş etme teorilerinde baş etme stratejileri, stres-uyum ilişkisinde önemli rol oynamaktadır. Baş etme, zorlayıcı olarak algılanan durumların üstesinden gelmeye yönelik bilişsel ve davranışsal çaba ve bu durumlarda ortaya çıkan negatif duyguları azaltmaya yönelik düzenleyici bir süreçtir ${ }^{38}$. Baş etme stratejileri, psikolojik semptomların gelişimini etkileyebilmekte, stresin olumsuz etkilerini hem kısa vadede hem de uzun vadede azaltabilmekte ve işlevsellik düzeyini artırabilmektedir ${ }^{39}$. Bu bağlamda kullanılan baş etme stratejileri stresle başa çıkarken önem kazanmakta ve kişinin anksiyete yaşama durumunu etkile-

33 James Rankin, a.g.e.

34 Gülin Nur Şahin, "Üniversite Öğrencilerinin Kendini Açma, Öznel İyi Oluş Ve Algıladıkları Sosyal Destek Düzeylerinin Karşılaştırılması”, (Yayımlanmamış Yüksek Lisans Tezi), Dokuz Eylül Üniversitesi, İzmir, 2011.

35 Ed Diener - Frank Fujita, "Resources, personal strivings, and subjective well-being: A nomothetic and idiographic approach", Journal of Personality and Social Psychology, cilt 68, say1 5, 1995, s. 926-935.

36 Kelley A. Tompkins - Kierra Brecht - Brock Tucker - Lucia L. Neander - Joshua K. Swift, "Who matters most? the contribution of faculty, student-peers, and outside support in predicting graduate student satisfaction", Training and Education in Professional Psychology, cilt 10, say1 2, 2016, s. 102-108.

37 Jihan Mahmoud - Ruth Staten - Lynne A. Hall - Terry A. Lennie, "The Relationship among young adult college students' depression, anxiety, stress, demographics, life satisfaction, and coping styles", Issues in Mental Health Nursing, cilt 33, say1 3, 2012, s. 149-156.

38 Susan Folkman - Richard S. Lazarus, Stress, Appraisal, And Coping, New York, Springer Publishing Company, 1984.

39 Daniel H. Romero - Shelley A. Riggs - Camilo Ruggero, "Coping, Family Social Support, And Psychological Symptoms Among Student Veterans", Journal of Counseling Psychology, cilt 62, say1 2, 2015, s. 242-252. 
mektedir ${ }^{4041}$. Lazarus ve Folkaman'1n ${ }^{42}$ geçiş modeli anksiyete ve baş etme arasındaki karşılıklı ilişkiye dikkat çeker. Anksiyete baş etme mekanizmasını motive ettiği gibi baş etme mekanizması da anksiyeteyi etkilemekte, durumu aktif bir şekilde değiştirebilmekte, sosyal desteği ortaya çıkarmakta, anksiyeteyi azaltmaya yönelik bilişsel değerlendirmeleri artırmakta veya dikkati başka yöne yönlendirebilmektedir ${ }^{43}$. Aktif baş etme stratejilerinin stresin etkilerini azalttığ 1 , pasif stratejilerin ise daha az etkili olduğu düşünülmektedir ${ }^{44}$.

Üniversite öğrencileriyle yapılan çalışmalar, aktif baş etme stratejilerini kullanan öğrencilerin üniversiteye daha iyi uyum sağladıklarını ve öznel iyi oluşlarının daha iyi olduğunu göstermektedir ${ }^{45}$. Ayrıca aktif baş etme stratejileri kullanan öğrenciler daha az psikolojik semptom göstermektedir. Crockett ve arkadaşlarının ${ }^{46}$ üniversite öğrencileriyle yaptıkları çalışma, uyumsuz baş etme stratejilerinin daha yüksek düzey anksiyete ile ilişkili olduğunu göstermektedir. Romero ve arkadaşlarının ${ }^{47}$ çalışması ise baş etme stratejilerinin ve sosyal desteğin anksiyete belirtilerini anlamlı ölçüde yordadığını ortaya koymaktadır. Ülev'in çalışmas ${ }^{48}$ ise aktif baş etme stratejilerinden kendine güvenli yaklaşım, iyimser yaklaşım ve sosyal destek arama yaklaşımı ile anksiyete arasında negatif bir ilişki; pasif baş etme stratejilerinden boyun eğici yaklaşım ve kendini suçlayıcı yaklaşım ile anksiyete arasında pozitif bir ilişki olduğunu bulgulamıştır. Bu çalışmalar ışığında, aktif baş etme stratejilerinin strese uyum gösterme çerçevesinde etkili olduğu söylenebilir.

Baş etme stratejileri, sosyal desteğin varlığ 1 ve ulaşılabilirliği uyum becerilerini etkilemektedir ${ }^{49}$. Bu nedenle, bu çalışmada baş etme tarzları ve algılanan

40 Agnes Szabo, a.g.e.

41 Jihan Mahmoud, a.g.e.

42 Susan Folkman, a.g.e.

43 Martin M. Smith - Donald H. Saklofske - Gonggu Yan - Simon B. Sherry, "Does perfectionism predict depression, anxiety, stress, and life satisfaction after controlling for neuroticism?" Journal of Individual, 38 (2), 2017, s. 892-906.

44 Lisa Crockett, a.g.e.

45 Kristen Kjerulff - Nancy H. Wiggins, "Graduate student styles for coping with stressful situations”, Journal of Educational Psychology, cilt 68, say1 3, 1976, s. 247-254.

46 Lisa Crockett, a.g.e.

47 Daniel H. Romero, a.g.e.

48 Esra Ülev, "Üniversite Öğrencilerinde Bilinçli Farkındalık Düzeyi İle Stresle Başa Çıkma Tarzının Depresyon, Kaygı ve Stres Belirtileriyle İlişkisi”, (Yayımlanmamış Yüksek Lisans Tezi), Hacettepe Üniversitesi, Ankara, 2014.

49 William E. Haley - Ellen G. Levine - Lane S. Brown - Alfred A. Bartolucci, "Stress, appraisal, coping, and social support as predictors of adaptation outcome among dementia caregivers", Psychology and Aging, cilt 2, say1 4, 1987, s. 323-330. 
sosyal destek düzeyinin üniversite öğrencilerinin uyum becerileriyle ilişkisi öznel iyi oluş bağlamında incelenecektir. Özetle bu çalışmanın amac1; 1) yurtta kalan ve kalmayan öğrencilerin baş etme stratejileri, sosyal destek, yaşam doyumu ve anksiyete puanları açısından farklılaşıp farklılaşmadığını, 2) baş etme stratejileri, yaşam doyumu ve algılanan sosyal desteğin anksiyete belirtileri üzerindeki etkisini, 3) anksiyete belirtileri, baş etme stratejileri ve algılanan sosyal desteğin yaşam doyumu düzeyi üzerindeki etkisini incelemektir. Araştırmanın soruları aşağıda sunulmuştur:

Hipotez 1: Öğrencilerin baş etme stratejileri, algıladıkları sosyal destek, anksiyete ve yaşam doyumu düzeyleri nerede/kiminle yaşadıklarına göre farklılaşmaktadır.

Hipotez 2: Algılanan sosyal destek ve yaşam doyumu puanları anksiyete puanlarını yordamaktadır.

Hipotez 3: Algılanan sosyal destek puanları yaşam doyumu puanlarını yordamaktadır.

Hipotez 4: Aktif baş etme stratejileri anksiyete puanlarını negatif yönde, pasif baş etme stratejileri anksiyete puanlarını pozitif yönde yordamaktadır.

Hipotez 5: Aktif baş etme stratejileri yaşam doyumunu pozitif yönde, pasif baş etme stratejileri ise negatif yönde yordamaktadır.

\section{Yöntem}

\section{Katılımelar}

Araştırmanın verileri kolay ulaşılabilir örnekleme yöntemi ile çeşitli üniversitelerde öğrenim görmekte olan üniversite öğrencilerinden toplanmıştır. Anketler araştırmaya katılmayı kabul eden öğrencilere dağıtılmış ve bir hafta sonra geri alınmıştır. Yurtta kalan öğrencilere ulaşabilmek için uygulamaya izin veren İstanbul ilindeki üç özel yurtta öğrencilere duyuru yapılmış ve gönüllü olan öğrenciler araştırmaya katılmıştır. Veri toplama işlemleri sonucunda tamamlanmış olan anketlerden yola çıkıldığında katılımcılar, yaş ortalaması 22.38 olan, toplam 206 kişiden (89=kadın, 116=erkek) oluşmaktadır. Katılımcıların \%51'i yurtta kalan öğrencilerden $(n=105), \% 32.5$ 'i ailesiyle $(n=67), \% 9.2$ 'si arkadaşlarıyla $(n=19)$, $\% 1.5$ 'i ise akrabasıyla $(n=3)$ yaşayanlardan oluşmaktadır. Katılımcıların \%95'i bekar, \%5'i ise evlidir. Katılımcıların önemli bir kısmı ekonomik durumlarını orta seviyede değerlendirmektedir ( $n=153)$. Katılımcıların büyük çoğunluğu $(n=202)$ lisans öğrencisiyken, çok az bir kısmı $(\mathrm{n}=2)$ ise yüksek lisans öğrencisidir. Öğrencilerin algılanan akademik başarıları ise orta $(n=97)$ ve iyi $(n=75)$ seviyelerde yoğunlaşmaktadır. 


\section{Veri Toplama Araçları}

Araştırmada kullanılan anket veri toplama araçları toplam 5 bölümden oluşmaktadır. İlk bölümde katılımcıların demografik özellikleri hakkında bilgi toplamayı sağlayan sorular bulunmaktadır. Diğer bölümlerde ise sırasıyla stresle başa çıkmay1, sosyal desteği, yaşam doyumunu ve anksiyeteyi ölçen ölçekler bulunmaktadır.

Yaşam Doyumu Ölçeği: Diener ve arkadaşları tarafından 1985 yılında geliştirilen Yaşam Doyumu Ölçeği (YDÖ) 5 maddeden oluşmakta ve her madde 7'li derecelendirme sistemine göre cevaplandırılmaktadır. YDÖ toplam puan ile çalışmakta ve ölçekten alınan puanların artması genel yaşam doyumunun arttığ1nı göstermektedir. Ölçeğin Türkçe'ye uyarlaması Köker ${ }^{50}$ tarafından yapılmıştır. Türkçe formunun madde-test korelasyonları .71 ve .80 arasında değişmektedir. Test-tekrar test katsayısı ise .85 bulunmuştur. Ölçeğin bu çalışmadaki iç tutarlılık katsayısı ise .85 olarak hesaplanmıştır.

Beck Anksiyete Ölçeği: Beck Anksiyete Envanteri (BAE) 1988 y1lında Beck ve arkadaşları tarafından geliştirilmiştir. BAE 21 maddeden oluşan, Likert tipi (0-3 arasında) bir öz bildirim ölçeğidir (Beck, Brown, Epstein, \& Steer, 1988). Ölçeğin iç tutarlılık katsayısı .90 'dır. Ölçek ilk olarak Nesrin Şahin tarafından ${ }^{51}$ Türkçe'ye çevrilmiş olup güvenirlik ve geçerlik çalışması Ulusoy ve arkadaşları 52 tarafından yapılmıştır. Puan Aralığ $10-63$ 'tür. Ölçekte alınan toplam puanların yüksekliği, bireyin yaşadığı anksiyetenin şiddetini gösterir. Ölçeğin kesme puanı 16 olarak belirlenmiş olup bu puanın üstü anksiyete belirtilerinin varlığına işaret etmektedir. Bu çalışmada BDE'nin, Ulusoy ve arkadaşları tarafından ${ }^{53}$ uyarlanan Türkçe versiyonu kullanılmıştır. Ölçeğin iç tutarlılık katsayısı bu çalışma için .93 olarak bulunmuştur.

Stresle Başa Çıkma Tarzları Ölçeği (SBTÖ): Folkman ve Lazarus tarafından 1980 yılında geliştirilen Başa Çıkma Yolları Envanteri 68 maddeden oluşan 4'lü likert tipi bir ölçektir. Stresle Başa Çıkma Tarzları Ölçeği (SBTÖ) Şahin ve Durak'ın ${ }^{54}$ bu ölçeği kısaltarak Türkçe'ye uyarladığı 30 maddeden oluşan

50 Süreyya Köker, "Normal ve Sorunlu Ergenlerin Yaşam Doyumu Düzeyinin Karşılaştırılması”, (Yayımlanmamış Yüksek Lisans Tezi), 1991.

51 Nesrin Hisli Şahin - Ayşegül Durak, "Stresle başa çıkma tarzları ölçeği: üniversite öğrencileri için uyarlanması", Türk Psikoloji Dergisi, cilt 10, say1 34, 1995, s. 56-73.

52 Mustafa Ulusoy - Nesrin Hisli Sahin - Hüsnü Erkmen, "Turkish version of the beck anxiety inventory", Journal of Cognitive Psychotherapy, cilt 12, 1988, s. 163-172.

53 a.g.e.

54 Nesrin Hisli Şahin, a.g.e. 
bir ölçektir. Ölçeğin yapı geçerliği için uygulanan faktör analizi kendine güvenli yaklaşım, iyimser yaklaşım, çaresiz yaklaşım, boyun eğici yaklaşım ve sosyal desteğe başvurma olmak üzere beş alt ölçeğin varlığını yansıtmıştır. İyimser Yaklaşım alt ölçeği için elde edilen güvenirlik katsayıları $\mathrm{a}=.68$ ile $\mathrm{a}=.49$ arasında değişmiştir. Bu değerler, "Kendine Güvenli Yaklaşım" alt ölçeği için a=.62 ile a=.80 arasında, "Çaresiz Yaklaşım" alt ölçeği için a=,64 ile a=.73 arasında, "Boyun Eğici Yaklaşım» alt ölçeği için de $\mathrm{a}=.47$ ile $\mathrm{a}=.72$ arasında bulunmuştur. «Sosyal Desteğe Başvurma» alt ölçeği için ise iç tutarlık katsayısı .47 ile .45 arasında değişmektedir. Bu çalışmada iç tutarlık katsayısı kendine güvenli yaklaşım için .70 , iyimser yaklaşım için .70, çaresiz yaklaşım için .75 , boyun eğici yaklaşım için .73 ve sosyal desteğe başvurma için .52 olarak hesaplanmıştır. Kendine güvenli, iyimser ve sosyal destek arama yaklaşımlarından elde edilen puanların artması etkili (aktif) başa çıkma stratejilerinin kullanıldığını; çaresiz ve boyun eğici yaklaşım alt boyutlarındaki artış ise etkisiz (pasif) başa çıkma stratejilerinin kullanıldığını göstermektedir ${ }^{55}$.

Çok Boyutlu Algılanan Sosyal Destek Ölçeği: Çok Boyutlu Algılanan Sosyal Destek Ölçeği (MSPSS) üç farklı kaynaktan alınan sosyal desteğin yeterliliğinin öznel değerlendirilmesi amacıyla Zimet ve arkadaşları (1988) tarafından geliştirilmiştir. Ölçek Eker ve Arkar ${ }^{56}$ tarafından Türkçe'ye çevrilmiştir. Aile, arkadaşlar ve özel bir insan olmak üzere üç alt ölçek bulunmaktadır. Alt ölçeklerin her biri 4 madde olmak üzere ölçek toplamda 12 maddeden oluşmaktadır. Her madde yedi aralıklı ölçek kullanılarak derecelendirilmiştir. MSPSS' in iç tutarlık katsayısı bu çalışmada .89 olarak bulunmuştur. Elde edilen puanın yüksek olması algılanan sosyal destek düzeyinin de yüksek olduğunu ifade etmektedir.

\section{İşlem}

Çalışma, gerekli etik düzenlemelere uygun olarak gerçekleştirilmiş ve üniversitenin etik kurulundan izin alınmıştır. Uygulamada gizlilik esası gözetilmiş ve araştırmaya katılan tüm örneklem grubundan bilgilendirilmiş onam alınmıştır. Uygulamaya katılan öğrencilerin anket formunu cevaplandırması yaklaşık 10-15 dakika sürmüştür.

\section{Verilerin Analizi}

Elde edilen verilerin analiz edilmesi için SPSS.21 (Statistical Package For The Social Sciences) paket programı kullanılmıştır. Değişkenler arasındaki ilişkileri görebilmek için korelasyon analizi (Pearson r) yapılmıştır. Hipotez testleri 
için bağımsız örneklem t testi ve hiyerarşik regresyon analizleri kullanılmıştır. Yapılan tüm analizler için normallik varsayımı sağlanmış ve basıklık ve çarpıklık katsayısı \pm 1.96 aralığında kabul edilmiştir. Örneklem grubunun betimleyici istatistiklerine ilişkin ortalama, standart sapma, frekans ve yüzde analizleri ve değişkenler arası korelasyon analizi yapılmıştır. Hiyerarşik regresyon analizinin varsayımlarının karşılanıp karşılanmadığı incelenmiş ve verilerin normal dağ1lıma uygun olduğu tespit edilmiştir. Yordayıcı değişkenler arasındaki korelasyon katsayılarının 0.595 ile 0.145 arasında olması nedeniyle çoklu bağlantısallık (multi-collinearity) problemi olmadığı belirlenmiştir. Çoklu doğrusal bağıntı ayrıca varyans büyütme faktörü $(\mathrm{VIF}<10)$, tolerans değeri (Tolerance $>0.20)$ ve durum indeksi $(\mathrm{CI}<30)$ değerleri ile de incelenmiştir.

\section{Bulgular \\ Ön Analizler}

Stresle başa çıkma tarzlarının alt boyutları arasındaki ilişkiyi incelemek için yapılan Pearson moment çarpım korelasyonu, kendine güvenli yaklaşım ile iyimser yaklaşım arasında orta düzeyde pozitif yönlü bir ilişki $(\mathrm{r}=.59, \mathrm{p}<.01)$, çaresiz ve boyun eğici yaklaşımlar arasında ise negatif yönlü zayıf bir ilişki (sırasıyla $\mathrm{r}=-.30, \mathrm{p}<.01 ; \mathrm{r}=-.23, \mathrm{p}<.01$ ) göstermiştir. Bununla birlikte iyimser yaklaşım ve çaresiz yaklaşım arasında zayıf ve negatif yönlü bir ilişki $(\mathrm{r}=-.15, \mathrm{p}<.01)$, çaresiz yaklaşım ve boyun eğici yaklaşım arasında ise güçlü ve pozitif yönlü bir ilişki bulunmuştur $(\mathrm{r}=.62, \mathrm{p}<.01)$. İyimser yaklaşım ile anksiyete arasında negatif yönlü zayıf, çaresiz yaklaşım ile pozitif yönlü zayıf bir ilişki görülmüştür.

Algılanan sosyal destek puanları $(O r t=60.20, S s=1.06)$ ile dört başa çıkma tarzı arasında anlamlı düzeyde ilişki bulunmuştur. Bunlardan pozitif yönlü ilişkide bulundukları kendine güvenli yaklaşım $(\mathrm{r}=.24, \mathrm{p}<.01)$, iyimser yaklaşım $(\mathrm{r}=.32, \mathrm{p}<.01)$ ve sosyal desteğe başvurma $(\mathrm{r}=.19, \mathrm{p}<.01)$ iken negatif yönlü ilişkide olduğu tek başa çıkma tarzı çaresiz yaklaşımdır $(\mathrm{r}=-$-. 24.--, $\mathrm{p}<.01)$. Algılanan sosyal destek ile anksiyete arasında ise zayıf ve negatif yönlü bir ilişki bulunmuş$\operatorname{tur}(\mathrm{r}=-.14, \mathrm{p}<.01)$.

Yaşam doyumu toplam puanları (Ort=21.87, $S s=.45)$ tüm diğer değişkenlerle anlamlı düzeyde ilişkili bulunmuştur. Boyun eğici yaklaşım, çaresiz yaklaşım ve anksiyete ile negatif yönlü (sırasılyla $\mathrm{r}=-.39, \mathrm{p}<.01 ; \mathrm{r}=-.19, \mathrm{p}<.01 ; \mathrm{r}=-.30, \mathrm{p}<.01$ ) bir ilişki bulgulanırken diğer değişkenlerle pozitif yönlü bir ilişkide olduğu görülmüştür. En güçlü korelasyonu ise algılanan sosyal destek ile göstermiştir $(\mathrm{r}=.50$, $\mathrm{p}<.01)$. 
Tablo 1. Değişkenlerin Ortalaması, Standart Sapması ve Korelasyon Katsayıları

\begin{tabular}{|c|c|c|c|c|c|c|c|c|c|}
\hline Değişkenler & Ort. & Ss & 2 & 3 & 4 & 5 & 6 & 7 & 8 \\
\hline $\begin{array}{l}\text { 1.Kendine } \\
\text { Güvenli } \\
\text { Yaklaşım }\end{array}$ & 20.98 & .26 & $.59 * *$ & .03 & $-.30 * *$ & $-.23 * *$ & $.24 * *$ & $.40 * *$ & -.12 \\
\hline $\begin{array}{l}\text { 2.İyimser } \\
\text { Yaklaşım }\end{array}$ & 13.87 & .20 & & -.00 & $-.15 * *$ & .01 & $.32 * *$ & $.27 * *$ & $-.15 * *$ \\
\hline $\begin{array}{l}\text { 3.Sosyal } \\
\text { Desteğe } \\
\text { Başvurma }\end{array}$ & 11.11 & .14 & & & -.06 & -.11 & $.19 * *$ & $.15^{* *}$ & .09 \\
\hline $\begin{array}{l}\text { 4.Çaresiz } \\
\text { Yaklaşım }\end{array}$ & 18.53 & .31 & & & & $.62 * *$ & $-.24 * *$ & $-.39 * *$ & $.19 * *$ \\
\hline $\begin{array}{l}\text { 5.Boyuneğici } \\
\text { Yaklaşım }\end{array}$ & 12.70 & .25 & & & & & -.07 & $-.19 * *$ & .03 \\
\hline $\begin{array}{l}\text { 6.Algılanan } \\
\text { Sosyal Destek }\end{array}$ & 60.20 & 1.06 & & & & & & $.50 * *$ & $-.14 * *$ \\
\hline $\begin{array}{l}\text { 7.Yaşam } \\
\text { Doyumu }\end{array}$ & 21.87 & .45 & & & & & & & $-.30 * *$ \\
\hline 8.Anksiyete & 14.72 & .87 & & & & & & & \\
\hline
\end{tabular}

$* p<.05, * * p<.01$

\section{Cinsiyete Göre Değişkenler Arasındaki Farklılıklar}

Sosyal destek, yaşam doyumu veanksiyete puanlarının cinsiyetle göre farkl11ık gösterip göstermadiğini saptamak amacıyla değişkenlere bağımsız örneklem t test hesaplamaları uygulanmıştır. Analiz sonuçları sosyal destek puanlarının cinsiyete göre anlamlı düzeyde farklı olduğu $\left(\mathrm{t}_{(190)}=2.621, \mathrm{p}<.01\right)$ ve kadınların (Ort=63.34, $S s=14.43)$ erkeklerden (Ort=57.75, Ss=15.66) daha fazla sosyal destek hissettiklerini ortaya koymaktadır. Kadınlar (Ort=23.19, $S S=5.73)$ erkeklerden $(O r t=21.02, S s=6.73)$ daha fazla yaşam doyumu bildirmişlerdir; $\mathfrak{t}(190)=2.443, \mathrm{p}<.05$. Kadınlar ve erkekler arasında anksiyete düzeyi bakımından da farklılaşma bulunmaktadır $\left(\mathrm{t}_{(190)}=1.993, \mathrm{p}<.05\right)$. Kadınlar $($ Ort $=16.69, S s=12.84)$ erkeklerden $(\mathrm{Ort}=13.20, S s=12.10)$ daha fazla anksiyete puanı almışlardır. 
Tablo 2. Değişkenlerin Cinsiyete Göre

Farklılaşmasına İlişkin Bulgular

\begin{tabular}{|c|c|c|c|c|c|c|c|c|}
\hline \multirow[b]{2}{*}{ Değişkenler } & \multicolumn{2}{|c|}{ Levene } & \multirow{2}{*}{$\mathrm{T}$} & \multirow{2}{*}{$\mathrm{P}$} & \multicolumn{2}{|c|}{ Kadın } & \multicolumn{2}{|l|}{ Erkek } \\
\hline & $\mathrm{F}$ & Sig. & & & Ort & Ss & Ort & Ss \\
\hline Anksiyete & 1.116 & .292 & 1.993 & .048 & 16.69 & 12.84 & 13.20 & 12.10 \\
\hline Yaşam Doyumu & 1.965 & .163 & 2.443 & .015 & 23.19 & 5.73 & 21.01 & 6.73 \\
\hline Algilanan Sosyal Detek & .563 & .454 & 2.621 & .009 & 63.34 & 14.43 & 57.75 & 15.66 \\
\hline
\end{tabular}

\section{Yaşadıkları Yerlere Göre Öğrencilerin Toplam Puanları Arasındaki Farklar}

Yurtta yaşayan ve diğerleriyle kalan öğrencilerin algılanan sosyal destek, yaşam doyumu, anksiyete ve başa çıkma stilleri alt ölçeklerinden aldıkları puanların farklılaşıp farklılaşmadığını görmek için Bağımsız Örneklem Testi analizi yapılmıştır. Ailesiyle, akrabalarıyla ve arkadaşlarıyla birlikte yaşayan öğrencilerin sayıları birbirine eşit olmadığından yurtta kalanlar ve diğer öğrenciler şeklinde ikili bir grup oluşturulmuştur. Sonuçlara göre yurtta kalanlar diğerleriyle yaşayanlardan daha az kendine güvenli başa çıkma puanına $\left(\mathrm{t}_{(201)}=-3.135, \mathrm{p}<.01\right)$; daha fazla çaresiz $\left(\mathrm{t}_{(201)}=-2.389, \mathrm{p}<.01\right)$ ve boyun eğici başa çıkma biçimi $\left(\mathrm{t}_{(201)}=\right.$ $4.000, \mathrm{p}<.01)$ puanına sahiptir. Yurtta yaşayan öğrencilerle diğerleri arasında algılanan sosyal destek puanları, yaşam doyumu ve anksiyete düzeyleri açısından bir farklılık görülmemektedir.

Tablo 3. Yurtta Kalan ve Diğerleriyle Yaşayan Öğrenciler Arasındaki Farklılığa İlişskin Bağımsız Örneklem t Testi

\begin{tabular}{|c|c|c|c|c|c|c|c|c|}
\hline \multirow[b]{2}{*}{ Değişkenler } & \multicolumn{2}{|c|}{ Levene } & \multirow[b]{2}{*}{$\mathrm{T}$} & \multirow[b]{2}{*}{$\mathrm{P}$} & \multicolumn{2}{|c|}{$\begin{array}{l}\text { Yurtta } \\
\text { Kalanlar }\end{array}$} & \multicolumn{2}{|c|}{$\begin{array}{l}\text { Diğerleriyle } \\
\text { Kalanlar }\end{array}$} \\
\hline & $\mathrm{F}$ & Sig. & & & Ort & Ss & Ort & Ss \\
\hline Algilanan Sosyal Destek & 0.35 & .851 & -.577 & .565 & 59.73 & 15.43 & 60.99 & 15.43 \\
\hline Yaşam Doyumu & 3.175 & .076 & -.462 & .645 & 21.69 & 7.29 & 22.11 & 5.66 \\
\hline $\begin{array}{l}\text { Kendine Güvenli Başa } \\
\text { Çıkma }\end{array}$ & .012 & .912 & -3.135 & .002 & 20.18 & 3.83 & 21.85 & 3.74 \\
\hline İyimse Başa Çıkma & .225 & .636 & .100 & .921 & 13.92 & 2.85 & 13.88 & 3.02 \\
\hline
\end{tabular}




\begin{tabular}{lcccccccc}
$\begin{array}{l}\text { Sosyal Destek Arayarak } \\
\text { Başa Çıkma }\end{array}$ & 2.488 & .116 & -.252 & .801 & 11.07 & 1.97 & 11.15 & 2.31 \\
Çaresiz Başa Çıkma & 0.007 & .931 & 2.389 & $\mathbf{. 0 1 8}$ & 19.35 & 4.58 & 17.82 & 4.57 \\
Boyun Eğici Başa & 1.750 & .187 & 4.000 & $\mathbf{. 0 0 0}$ & 13.70 & 3.60 & 11.72 & 3.42 \\
Çıkma & & & & & & & & \\
Anksiyete & 0.856 & .356 & -1.372 & $\mathbf{. 1 7 2}$ & 13.56 & 12.84 & 15.99 & 12.27 \\
\hline
\end{tabular}

\section{Yordayıcı Değişkenlerin İncelenmesi}

\section{Yaşam Doyumunu Yordayan Değişkenlerin İncelenmesi}

Yaşam doyumunu yordayan değişkenleri incelemek için yapılan Regresyon Analizinin ilk basamağına cinsiyet ve yurtta kalıp kalmama değişkenleri konmuştur ve yalnızca cinsiyetin anlamlı düzeyde yordayıcı rolü görülürken $(\mathrm{p}<.05)$ her iki değişkenin birlikte yaşam doyumuyla ilişki olduğu görülmüştür $(\mathrm{R}=.174$, $\mathrm{R}^{2}=.03$ ). Bu model yaşam doyumunun yalnızca \%3'nü açıklamaktadır. İkinci modelde baş etme tarzlarının tümü birlikte analize dahil edilmiştir ve yaşam doyumunu yordadıkları görülmüştür $\left(\mathrm{R}=.174, \mathrm{R}^{2}=.312\right)$. İkinci modelde açıklanan varyans \%31'e çıkmıştır. İkinci modeldeki değişkenler tek tek incelendiğinde yalnızca çaresiz $(\mathrm{p}<.001)$ ve kendine güvenli yaklaşımın $(\mathrm{p}=.001)$ anlamlı yordayıcı oldukları görülmektedir. Standartlaştırılmış regresyon katsayılarına göre anlamlı değişkenlerin göreli önem sırası, çaresiz yaklaşım ( $\beta=-.364)$ ve kendine güvenli yaklaşım $(\beta=.269)$ şeklindedir. Bunlardan ilki yaşam doyumunu negatif, ikincisi ise pozitif yönde yordamaktadır. Üçüncü adımda analize algılanan sosyal destek ile anksiyete puanları girilmiş ve elde edilen model anlamlı çıkmıştır $\left(\mathrm{R}=67.4, \mathrm{R}^{2}=.454\right)$ ve açıklanan varyansın da $\% 45$ 'e yükseldiği görülmüştür. $\mathrm{Bu}$ adımdaki her iki değişken de anlamlıdır ve standartlaştırılmış katsayıları incelendiğinde pozitif yönlü yordayıcı olan algılanan sosyal desteğin $(\beta=.347)$, negatif yönlü yordayıcı olan anksiyeteden $(\beta=-.199)$ görece daha önemli oldu$\breve{g u}$ bulunmuştur. Bu çalışmaya katılan öğrencilerin algıladıkları sosyal destek arttıkça yaşam doyumları da artmakta ve anksiyete düzeyleri arttıkça yaşamdan aldıkları doyum azalmaktadır. Aktif baş etme stratejilerinin yaşam doyumunu pozitif yönde ve pasif baş etme stratejilerinin ise negatif yönde yordadığı şeklindeki hipotez ise kısmen desteklenmiştir. Çünkü modelin ikinci adımında aktif baş etme stratejilerinden yalnızca kendine güvenli yaklaşım ve pasif baş etme stratejilerinden ise yalnızca çaresiz yaklaşım yaşam doyumunu öngörülen yönde açıklamışlardır. 
Tablo 4. Yaşam Doyumunu Yordayan Değişkenlere İlişkin Hiyerarşik Regresyon Analizi

\begin{tabular}{|c|c|c|c|c|c|}
\hline \multirow{4}{*}{$\begin{array}{l}\text { Bağımsız Değişkenler } \\
\text { Düzeltilmiş } \mathbf{R}^{2}: .42 \\
\text { Denklemdeki Değişkenler }\end{array}$} & \multicolumn{5}{|c|}{ Yaşam Doyumu } \\
\hline & \multicolumn{5}{|c|}{$\begin{array}{l}\text { Demografik Değişkenler, Stresle Başa } \\
\text { Çıkma Tarzları, Anksiyete, Algılanan } \\
\text { Sosyal Destek }\end{array}$} \\
\hline & \multicolumn{2}{|c|}{ F testi: 17.95} & \multicolumn{2}{|c|}{ Anlamlılık:.000 } & \\
\hline & Beta & $\mathrm{T}$ & $\mathrm{P}$ & $\mathrm{R}$ & $\mathrm{R}^{2}$ \\
\hline 1. Adım: Demografik Değişkenler & & & & .174 & .030 \\
\hline Cinsiyet & -.175 & -2.491 & .014 & & \\
\hline Yurtta kalıp kalmama & -.015 & -.211 & .833 & & \\
\hline 2. Adım: Stresle Başa Çıkma Tarzları & & & & .559 & .312 \\
\hline İyimser Yaklaşım & .085 & 1.095 & .275 & & \\
\hline Çaresiz Yaklaşım & -.364 & -4.647 & .000 & & \\
\hline Kendine Güvenli Yaklaşım & .269 & 3.356 & .001 & & \\
\hline Sosyal Destek Arama & .106 & 1.771 & .078 & & \\
\hline Boyun Eğici Yaklaşım & .061 & .750 & .454 & & \\
\hline 3. Adım: Diğer Yordayıcı Değişkenler & & & & .674 & .454 \\
\hline Algilanan Sosyal Destek & .347 & 5.734 & .000 & & \\
\hline Anksiyete & -.199 & -3.540 & .001 & & \\
\hline
\end{tabular}

\section{Anksiyeteyi Yordayan Değişkenlerin İncelenmesi}

Anksiyeteyi yordayan değişkenleri incelemek için yapılan Regresyon Analizinin ilk basamağına cinsiyet ve yurtta kalıp kalmama değişkenleri konmuştur ve anksiyeteyle ilişkilerinin anlamsız olduğu görülmüştür $\left(\mathrm{R}=.157, \mathrm{R}^{2}=.002\right)$. Modelin ikinci adımında baş etme stratejileri eklenmiş ve yalnızca çaresiz baş etmenin anlamlı bir yordayıcı olduğu görülmüştür $(\mathrm{p}<.01)$. İkinci model ile birlikte varyansın \%8'i açıklanmıştır. Beta puanları incelendiğinde çaresiz baş etme stratejisinin anksiyeteyi pozitif yönde yordadığ 1 görülmektedir. Öğrenciler çaresiz baş etme stratejisi kullandıkça anksiyeteleri artmaktadır. Modelin üçüncü adımında ise algılanan sosyal destek ile yaşam doyumu analize girilmiş ve yalnızca yaşam doyumunun anlamlı yordayıcı olduğu $(\mathrm{p}<.001)$, açıklanan var- 
yansın da \%14.3'e çıktığı görülmüştür. Beta puanları incelendiğinde yaşam doyumunun anksiyeteyi negatif yönde yordadığı, yani yaşam doyumu arttıkça anksiyetenin azaldığ

Tablo 5. Anksiyeteyi Yordayan Değişkenlere İlişkin Hiyerarşik Regresyon Analizi

\begin{tabular}{|c|c|c|c|c|c|}
\hline Bağımlı Değişken & \multicolumn{5}{|c|}{ Anksiyete } \\
\hline Bağımsız Değişkenler & \multicolumn{5}{|c|}{$\begin{array}{l}\text { Demografik Değişkenler, Stresle Başa } \\
\text { Çıkma Tarzları, Yaşam Doyumu, Algılanan } \\
\text { Sosyal Destek }\end{array}$} \\
\hline Düzeltilmiş $\mathbf{R}^{2}: .11$ & \multicolumn{4}{|c|}{ F testi: 5.45} & \multirow[b]{2}{*}{$\mathrm{R}^{2}$} \\
\hline Denklemdeki Değişkenler & Beta & $\mathrm{T}$ & $\mathrm{P}$ & $\mathrm{R}$ & \\
\hline 1. Adım: Demografik Değişkenler & & & & .157 & .002 \\
\hline Cinsiyet & -.124 & -1.754 & .081 & & \\
\hline Yurtta kalıp kalmama & .078 & 1.108 & .269 & & \\
\hline 2. Adım: Stresle Başa Çıkma Tarzları & & & & .283 & .080 \\
\hline İyimser Yaklaşım & -.120 & -1.740 & .083 & & \\
\hline Çaresiz Yaklaşım & .188 & 2.684 & .008 & & \\
\hline 3. Adım: Diğer Yordayıcı Değişkenler & & & & .378 & .143 \\
\hline Algılanan Sosyal Destek & -.294 & -3.519 & .908 & & \\
\hline Yaşam Doyumu & .009 & .116 & .001 & & \\
\hline
\end{tabular}

\section{Tartışma}

$\mathrm{Bu}$ araştırma yurtta yaşayanlar ile ailesiyle, arkadaşlarıyla ya da akrabalarıyla yaşayan öğrencilerin algıladıkları sosyal destek düzeyleri ve baş etme stratejileri bakımından farklılıklarını ve bu farklılıklarının yaşamdan aldıkları doyumu ve anksiyete düzeylerini ne şekilde açıkladığını incelemektedir. Böylece yurt yaşamının koruyucu bir faktör olarak öğrencilerin sosyal destek ihtiyaçlarını destekleyip desteklemediği irdelenmeye çalışılmıştır. Bununla birlikte, yaşadıkları yerin öğrencilerin kullandıkları baş etme stratejileriyle ilişkisi de ele alınmıştır. Son olarak kişilik özelliği olarak baş etme stratejilerinin ve çevresel etmen olarak sosyal desteğin öğrencilerin yaşam doyumlarını ve anksiyetelerini ne şekilde açıkladığı araştırılmıştır. 
Ön analizler katılımcıların cinsiyetlerine göre sosyal destek, yaşam doyumu ve anksiyete düzeylerinin farklılık göstermiş olup kadınların her üç değişkende de erkeklerden daha fazla puan aldıklarını göstermiştir. Sosyal destek üzerinde yapılan önceki araştırmalarda da benzer sonuçları görmek mümkündür ${ }^{57} 58$. Bununla birlikte, mevcut çalışmada olduğu gibi kadınların erkeklerden anlamlı düzeyde daha fazla yaşam doyumu bildirdikleri araştırmalar bulunduğu gibi 59 anlamlı fark göstermeyen çalışmalar da bulunmaktadır ${ }^{60}{ }^{61}$. Çalışmanın bulgular1, kadınların anksiyete düzeylerinin erkeklerden daha yüksek olduğunu gösteren önceki araştırmaları desteklemektedir ${ }^{62} 63$.

Hipotez testleri incelendiğinde yaşadıkları yere göre öğrencilerin algılanan sosyal destek puanlarının farklılaşmadığı görülmüştür. Dolayısıyla sonuçlar, yurt yaşamının öğrencilere diğer ortamlardakine benzer bir sosyal destek sağladığ şeklinde yorumlanmaya müsait olsa da daha fazla araştırılmaya ihtiyaç hissettirmektedir. Zira genç yetişkinlerin ailelerinden çok arkadaşlarının desteğine yönelmesi gibi gelişimsel bir özelliğin ${ }^{64}$ ya da yurtta yaşamasına rağmen ailelerinin desteğini hissedebilmeleri gibi güçlü aile ilişkileri gibi bir çevresel etmenin bulgular üzerinde karıştırıcı değişken rolü oynayıp oynamadığı araştırmanın sınırlılıkları gereği kontrol edilememiştir.

Baş etme stratejileriyle ilgili 3. dalga teoriler kişilik özelliklerinin baş etme üzerindeki etkisine dikkat çekerek bireyin baş etme kapasitesinin strese verilen reaksiyonları (anksiyete gibi) azaltabildiğini ileri sürmektedir ${ }^{65}$. Bu çalışmanın bulguları ise baş etme stratejilerinden yalnızca çaresiz yaklaşım ve anksiyete ara-

57 Donice M. Banks, a.g.e.

58 Juyeon Song, a.g.e.

59 Isolde Daig - Peter Herschbach - Anja Lehmann - Nina Knoll - Oliver Decker, "Gender and age differences in domain-specific life satisfaction and the impact of depressive and anxiety symptoms: a general population survey from german", Quality of Life Research, cilt 18, say1 6, 2009, 669-678.

60 Hatice Odac1, a.g.e.

61 Carolyn MacCann- Anastasiya A. Lipnevich - Jeremy Burrus - Richard D Roberts, "The best years of our lives? coping with stress predicts school grades, life satisfaction, and feelings about high school”, Learning and Individual Differences, cilt 22, say1 2, 2012, s. 235-241.

62 Isolde Daig, a.g.e.

63 Jihan Mahmoud, a.g.e.

64 Patricia H. Miller, Gelişim Psikolojisi Kuramları, çev. Zeynep Gültekin, İstanbul, İmge Kitabevi, 2008.

65 Ingrid K. Weigold - Christine Robitscheck, "Agentic personality characteristics and coping: their relation to trait anxiety in college students", American Journal of Orthopsychiatry, cilt 81, say1 2, 2011, s. 255-264. 
sında bir ilişki ortaya koymuş ve stresle baş etmede çaresiz bir tutum sergileyenlerin anksiyete düzeylerinin daha yüksek olduğunu ortaya koymuştur.

Baş etme stratejileriyle ilgili 2. dalga teoriler ise durumsal stresörlerin baş etme biçimini belirlediğini öne sürmektedir ${ }^{66}$. Dolayısıyla yurt yaşamının öğrencilerin stresle başa çıkma ve stres reaksiyonları (anksiyete) ile ilişkisi ise 2. dalga teoriler bağlamında incelenmeye elverişlidir. Üniversite öğrencilerinin nerede ve kimlerle yaşadıklarının durumsal bir stresör olup olmadığı bu çalışma bağlamında incelenmiş ve anksiyete ile ilişkili olmadığ bulgulanmıştır.

Araştırma bulgularına göre yurtta yaşayanlar ile diğer öğrenciler (ailesiyle, arkadaşlarıyla ve akrabalarıyla yaşayanlar) arasında baş etme stratejilerinin farkl1laştı̆̆1 görülmektedir. Yurtta yaşayan öğrenciler (Ort= 20.18) diğer öğrencilere kıyasla $(\mathrm{Ort}=21.85)$ daha az kendine güvenli yaklaşım bildirmişlerdir. Bununla birlikte yurtta yaşayan öğrenciler, diğer öğrencilerden daha fazla boyun eğici ve çaresiz baş etme stratejisi bildirmiştir. Başka bir deyişle, bulgular pasif baş etme stratejilerini kullanma eğiliminin yurtta kalan öğrencilerde diğerlerinden daha fazla olduğunu düşündürmektedir. Bu nedenle her ne kadar algıladıkları sosyal destek bakımından diğer gruptakilerden farklılaşmasalar da stresle baş etme yöntemleri incelendiğinde daha dezavantajlı göründüklerini söylemek uygun olabilir. $\mathrm{Bu}$ bulgular yurt yaşamının durumsal bir stresör olabileceğini ve baş etme biçimlerine etki ettiğini düşündürmektedir ${ }^{67}$. Bununla beraber literatürde yurtta, ailesiyle birlikte ya da yalnız yaşamanın baş etme stratejileriyle ilişkisini inceleyen çalışmalar bulunmamaktadır. Bu bakımdan mevcut araştırmanın bu alandaki ilk bulgulara katkı sunduğu söylenebilir.

Algılanan sosyal destek ve yaşam doyumunun anksiyeteyi negatif yönde yordadığına dair hipotez kısmen desteklenmiş ve yalnızca yaşam doyumunun beklenen yönde anlamlı bir açıklayıcı olduğu görülmektedir. Algılanan sosyal desteğin anksiyete üzerinde yordayıcı etkisinin görülmemesi ise literatür 1şığında değerlendirildiğinde şaşırtıcı olmayabilir. Çünkü iki değişken arasında ilişki bulan Eker ve Arkar'ın (1995) çalışmasındaki r=-.35 değeri de güçlü bir ilişkiye işaret etmemektedir. Diğer yandan sosyal desteğin anksiyeteyi negatif yönde yordadığını ortaya koyan çalışmalar da bulunmaktadır ${ }^{68}{ }^{69}$. Katılımcıların öğrenci oldukları ve sosyal desteği hissetme bakımından cinsiyet kategorisi dışında homojen oldukları dikkate alındığında, anksiyeteyi açıklayacak fakat araştırmaya dahil edilmemiş başka değişkenlerin varlığı olası görünmektedir. Algılanan sos-

66 a.g.e.

67 a.g.e.

68 Lisa Crockett, a.g.e.

69 Daniel H. Romero, a.g.e. 
yal desteğin aksine yaşam doyumunun anksiyeteyi anlamlı düzeyde yordaması ise Mahmoud ve arkadaşlarının (2012) çalışmalarını desteklemektedir.

Üçüncü hipotezi destekler biçimde, algılanan sosyal destek yaşam doyumunu yordamaktadır ve bu durum iki değiş̧en arasındaki güçlü korelasyonla da tutarlı görünmektedir. Katılımcıların sosyal çevrelerinin desteğini hissetmeleri onların yaşamdan aldıkları doyumu artırmaktadır ve bu bağlamda bulgular literatür ile tutarl111k göstermektedir (Gayathri ve Karthikeyan, 2016; Diener ve Fujita, 1995; Tompkins ve ark., 2016).

Anksiyete ve yaşam doyumu değişkenleri literatürde karşılıklı birbirlerini yordayıcı değişkenler olarak incelenmektedir. Bulgular, anksiyetenin öznel iyi oluşla negatif yönlü ilişkisini gösteren önceki çalışmalarla tutarlıdır ${ }^{707172}$. Dolay1sıyla katılımcıların anksiyete düzeyleri arttıkça yaşamdan daha az doyum aldıklarını söylemek mümkündür. Bununla birlikte anksiyete yaşam doyumunun daha güçlü bir yordayıcısıdır.

$\mathrm{Bu}$ araştırmanın bulguları yalnızca tek bir pasif baş etme starejisinin (çaresiz yaklaşım) anksiyeteyi olumsuz yordadığını göstererek Crockett ve arkadaşları$\mathrm{n}^{73}{ }^{73}$ elde ettikleri sonuçları kısmen desteklemektedir. Bunun nedeni Crockett ve arkadaşlarının aktif ve pasif baş etme stratejileri şeklinde ikili kategorizasyon üzerinden inceleme yürütmelerine karşın bu çalışmada beş baş etme stratejisinden her birinin ayrı ayrı analize dahil edilmesi olabilir. Benzer bir sonucu Romero ve arkadaşlarının ${ }^{74}$ çalışmasında da görmek mümkündür. Bununla beraber Ülev' in ${ }^{75}$ araştırması kendine güvenli yaklaşım, iyimser yaklaşım ve sosyal destek arama yaklaşımı ile anksiyete arasında negatif yönde anlamlı bir ilişki; kendini suçlayıcı yaklaşım ve boyun eğici yaklaşım ile anksiyete arasında pozitif yönde anlamlı ilişki bulgulamıştır. Oysa daha önce belirtildiği gibi bu çalışmada yalnızca bir baş etme stratejisi anlamlı yordayıcı olarak bulgulanmıştır.

Baş etme mekanizmalarının kişinin ruh sağlığını ve yaşamdan aldığ doyumu etkilediğini ${ }^{76}{ }^{77}$, hatta yaşam doyumunu yordadı ${ }^{1} 11^{78}$ gösteren çalışmalar bu araş-

70 Isolde Daig, a.g.e.

71 Jihan Mahmoud, a.g.e.

72 Martin M. Smith, a.g.e.

73 Lisa Crockett, a.g.e.

74 Daniel H. Romero, a.g.e.

75 Esra Ülev, a.g.e.

76 Hatice Odac1, a.g.e.

77 Errol Hamarat, a.g.e.

78 Shown O. Utsey - Joseph G. Ponterotto - Amy L. Reynolds - Anthony A. Cancelli, "Raci- 
tırmanın bulgularınca kısmen desteklenmektedir. Bu çalışmada bir aktif baş etme stratejisinin (kendine güvenli yaklaşım) ve bir de pasif baş etme stratejisinin (çaresiz yaklaşım) yaşam doyumu üzerindeki yordayıcı etkisi ortaya konmaktayken, bahsi geçen önceki çalışmaların aktif ve pasif stratejiler şeklinde iki alt boyutlu bir inceleme yürüttüğü görülmektedir. Dolayısıyla bu durum söz konusu kısmi tutarlılığa yol açmış olabilir.

Yurt öğrencileriyle yapılan çalışmalar kişilik özelliklerinin yurt yaşamına uyum sağlama, mekana bağlanma, aileden bağımsızlaşmayı etkilediğini göstermektedir. ${ }^{79}$ Uslu ve Girgin' in ${ }^{80}$ çalışması ise ailelerden daha erken bağımsızlaşan (yurtta veya arkadaşlarıyla yaşayan) üniversite öğrencilerinin, aileleriyle birlikte yaşayanlara göre problem çözme becerilerinin daha yüksek olduğunu göstermektedir. Sonuç olarak bu çalışmaya katılan üniversite öğrencilerinin yaşadıkları yere göre farklı düzeylerde sosyal destek algılamadıkları, ancak farklı baş etme stratejileri kullandıkları tespit edilmiştir. Üstelik yurtta kalanların daha yüksek düzeyde çaresiz ile boyun eğici ve daha düşük düzeyde kendine güvenli yaklaşımı benimsemeleri, kişisel özellikler bakımından dezavantajlı olduklarını düşündürmektedir. Bu durum, bireyselleşme ve bağımsızlaşma süreçlerinin tamamlanamaması ile açıklanabilir. ${ }^{81}$ Bireyselleşme ve ayrışma ise bireysel gelişim sürecinin önemli bir parçasıdır. ${ }^{82}$ Üniversite öğrencilerinin yaşadıkları yere göre başa çıkma biçimlerindeki bu farklılaşma bireyselleşme ve ayrışma süreçlerinde yaşanan güçlükler çerçevesinde düşünülebilir. $\mathrm{Bu}$ konuyla ilgili daha fazla çalışma yapılması ve bireyselleşmeyle ilgili değişkenlerin de incelenmesi, yurtta kalan öğrencilerin pasif baş etme stratejilerini daha fazla kullanma eğilimlerini açıklamaya yardımcı olacaktır.

Pasif baş etme stratejilerinin anksiyeteyle pozitif yönlü ilişkisi yurtta kalan öğrencilerin bu yönden risk taşıyabilecekleri ihtimâlini değerlendirmeye aç-

al Discrimination, Coping, Life Satisfaction, And Self-Esteem Among African Americans", Journal of Counseling and Development, cilt 78, say1 1, 2000, s. 72-80.

79 J. Tognoli, "Leaving Home”, Journal of College Student Psychotherapy, cilt 18, say1 1, 2003, s. $35-48$.

80 Mustafa Uslu - Çağla Girgin, "The Effects Of Residential Conditions On The Problem Solving Skills Of University Students”, Procedia Social and Behavioral Sciences, cilt 2, say1 2, 2010 , s. 3031-3035.

81 Stephen. A. Anderson - Ronald. M. Sabatelli, "Differentiating Differentiation And Individuation: Conceptual And Operation Challenges", American Journal of Family Therapy, cilt 18, say1 1, 1990, s. 32-50.

82 Çiğdem Kağıtçıbaşı, "Autonomy and relatedness in cultural context implications for self and family", Journal of Cross-Cultural Psychology, cilt 36, say1 4, 2005, s. 403-422. 
maktadır. Sosyal desteğin stresin negatif etkilerine karşı koruyucu işlev gördüğü öne sürülmüştür. ${ }^{83}$ Dolayısıyla öğrenciler yurt ortamında güçlü bir sosyal destek bulabilirse, yaşam doyumları da bundan olumlu yönde etkilenebilecek ve dolayısıyla anksiyete düzeyleri azalabilecektir. Böylece sahip oldukları baş etme stratejisi dezavantajının öznel iyi oluşları üzerindeki olumsuz etkisi de azaltılabilecektir. Dolayısıyla yurt ortamlarında kalan öğrencilerin sosyal destek ağlarını geliştirebilmelerine, yurdun kendi içerisinde bu imkânı sağlamasına veya öğrencilerin kaynaşmalarına yönelik çalışmalar yapmanın faydalı olabileceği düşünülmektedir.

83 Doğan Eker, a.g.e. 


\section{Kaynakça}

Adams, Gary. A. - King, Lynda A. - King, Daniel. W., "Relationships of Job and Family Involvement, Family Social Support, and Work-Family Conflict with Job and Life Satisfaction”, Journal of Applied Psychology, cilt 81, say1 4, 1996, (http://doi.org/: 10.1037/0021-9010.81.4.411).

Anderson, Stephen. A. - Sabatelli, Ronald. M., "Differentiating Differentiation and Individuation: Conceptual and Operation Challenges", American Journal of Family Therapy, cilt 18, say1 1, 1990, (http://doi.org/: 10.1080/01926189008250790).

Aquino, Juan. A., - Russell, Daniel. W. - Cutrona, Carolyn E. - Altmaier, Elizabeth. M., "Employment Status, Social Support, and Life Satisfaction Among The Elderly", Journal of Counseling Psychology, cilt 43, say1 4.

Banks, Donice M. - Weems, Carl F., "Family and Peer Social Support and Their Links to Psychological Distress Among Hurricane-Exposed Minority Youth", American Journal of Orthopsychiatry, cilt 84, say1 4, (http://doi.org/:10.1037/ ort0000006).

Beck, Aaron. T. - Epstein, Norman - Brown, Gary - Steer, Robert A., "An Inventory for Measuring Clinical Anxiety: Psychometric properties", Journal of Consulting and Clinical Psychology, cilt 56, say1 6, 1988, (http://doi. org/: 10.1037/0022-006X.56.6.893).

Ben-Zur, Hasida, "Coping Styles and Affect", International Journal of Stress Management, cilt 16, say1 2, 2009, (http://doi.org/: 10.1037/a0015731).

Campos, Belinda - Schetter, Cristine Dunkel - Abdou, Cleopatra M. - Hobel, Calvin J. - Glynn, Laura M. - Sandman, Curt A., "Familialism, Social Support, and Stress: Positive Implications for Pregnant Latinas", Cultural Diversity And Ethnic Minority Psychology, cilt 14, say1 2, 2008, (http://doi.org/: 10.1037/10999809.14.2.155).

Chen, Wanfen - Zhang, Dajun - Pan, Yangu - Hu, Tianqiang - Liu, Guangzeng - Luo, Shilan, "Perceived Social Support and Self-Esteem as Mediators of The Relationship Between Parental Attachment and Life Satisfaction Among Chinese Adolescents", Personality and Individual Differences, cilt 108, 2017, (https://doi. org/10.1016/j.paid.2016.12.009).

Clark, Heddy Kovach - Murdock, Nancy L. - Koetting, Kristin, "Predicting Burnout and Career Choice Satisfaction In Counseling Psychology Graduate Students", The Counseling Psychologist, cilt 37, 2009, (https://doi. org/10.1177/0011000008319985). 
Cohen, Sheldon - Sherrod, Drury R. - Clark, Margaret S., "Social Skills and The Stress-Protective Role of Social Support", Journal of Personality and Social Psychology, cilt 50, say1 5, 1986, (https://doi.org/10.1037/0022-3514.50.5.963).

Cohen, Sheldon - Wills, Thomas A., "Stress, Social Support, and The Buffering Hypothesis", Psychological Bulletin, cilt 98, 1985, (https://doi. org/10.1037/0033-2909.98.2.310).

Crockett, Lisa J. - Iturbide, Maria I. - Thores Stone, Rosalie - McGinley, Meredith - Raffaelli, Marcela - Carlo, Gustavo, "Acculturative Stress, Social Support, and Coping: Relations to Psychological Adjustment Among Mexican American College Students", Cultural Diversity and Ethnic Minority Psychology, cilt 13, say1 4, 2007, (https://doi.org/10.1037/1099-9809.13.4.347).

Daig, Isolde - Herschbach, Peter - Lehmann, Anja - Knoll, Nina - Decker, Oliver, "Gender and Age Differences in Domain-Specific Life Satisfaction and The Impact of Depressive and Anxiety Symptoms: A General Population Survey From German", Quality of Life Research, cilt 18, say1 6, 2009, (http://doi.org/: 10.1007/s1 1136-009-9481-3).

Diener, Ed - Fujita, Frank, "Resources, personal strivings, and subjective well-being: A nomothetic and idiographic approach", Journal of Personality and Social Psychology, cilt 68, say1 5, 1995, (https://doi.org/10.1037/00223514.68.5.926).

Diener, Ed - Diener, Marissa, "Cross-cultural correlates of life satisfaction and self-esteem", E. Diener içinde, Culture and Well-Being, The Collected Works of Ed Diener, New York, Springer, 2009.

Eker, Doğan - Arkar, Haluk, "Çok Boyutlu Algılanan Sosyal Destek Ölçeği'nin Faktör Yapısı, Geçerlik ve Güvenirliği”, Türk Psikoloji Dergisi, cilt 10, say1 34, 1995.

Friedlander, Laura J. - Reid, Graham J. - Shupak, Naomi - Cribbie, Robert, "Social Support, Self-Esteem, and Stress as Predictors of Adjustment to University Among First-Year Undergraduates", Journal of College Student Development, cilt 48, say1 3, 2007, (http://doi.org/: 10.1353/csd.2007.0024).

Haley, William E. - Levine, Ellen G. - Brown, S. Lane - Bartolucci, Alfred A., "Stress, Appraisal, Coping, And Social Support as Predictors of Adaptation Outcome Among Dementia Caregivers", Psychology and Aging, cilt 2, say1 4, 1987, (https://doi.org/10.1080/036107301750074051).

Hamarat, Errol - Thompson, Dennis - Zabrucky, Karen M. - Steele, Don Matheny, Kenneth B. - Aysan, Ferda, "Perceived Stress and Coping Resource 
Availability as Predictors of Life Satisfaction In Young", Middle-Aged, And Older Adults, Experimental Aging Research, cilt 27, 2001.

Headey, Bruce - Kelley, Jonathan - Wearing, Alex, "Dimensions of Mental Health: Life Satisfaction, Positive Affect, Anxiety and Depression", Social Indicators Research, cilt 29, 1993.

Gayathri, Nagarajan - Karthikeyan, Parthasarathy, "The Role of Self-Efficacy and Social Support In Improving Life Satisfaction", Zeitschrift für Psychologie, cilt 224, say1 1, 2016, (http://doi.org/:10.1027/2151-2604/a000235)

Kağıtçıbaşı, Çiğdem, "Autonomy and relatedness in cultural context implications for self and family", Journal of Cross-Cultural Psychology, cilt 36, say1 4, 2005, (http://doi.org/:10.1177/0022022105275959).

Kapıkıran, Şahin, "Loneliness and Life Satisfaction in Turkish Early Adolescents: The Mediating Role of Self-Esteem and Social Support", Social Indicators Research, cilt 111, say1 2, 2013, (http://doi.org/: 10.1007/s11205-012-0024-x).

Kjerulff, Kristen - Wiggins, Nancy H., "Graduate Student Styles for Coping with Stressful Situations", Journal of Educational Psychology, cilt 68, say1 3, 1976.

Köker, Süreyya, "Normal ve Sorunlu Ergenlerin Yaşam Doyumu Düzeyinin Karşılaştırılması", (Yayımlanmamış Yüksek Lisans Tezi), 1991.

Folkman, Susan - Richard S. Lazarus, Stress, Appraisal, And Coping, New York, Springer Publishing Company, 1984.

MacCann, Carolyn - Lipnevich, Anastasiya A. - Burrus, Jeremy - Roberts, Richard D., "The Best Years of Our Lives? Coping with Stress Predicts School Grades, Life Satisfaction, and Feelings About High School", Learning and Individual Differences, cilt 22, say1 2, 2012, (http//doi.org/:10.1016/j.lindif.2011.08.004).

Mahmoud, Jihan - Staten, Ruth - Hall, Lynne A. - Lennie, Terry A., “The Relationship among young adult college students' depression, anxiety, stress, demographics, life satisfaction, and coping styles", Issues in Mental Health Nursing, cilt 33, say1 3, Şubat 2012, (http://doi.org:10.3109/01612840.2011.632708).

Miller, Patricia H., Gelişim Psikolojisi Kuramları, çev. Zeynep Gültekin, İstanbul, İmge Kitabevi, 2008.

Odacı, Hatice - Çıkrıkçı, Özkan, "University Students' Ways of Coping with Stress, Life Satisfaction and Subjective Well-Being", TOJCE: The Online Journal of Counselling and Education, cilt 1, say1 3, 2012. 
Oswalt, Sara B. - Riddock, Christina C., "What Do About Being Overwhelmed: Graduate Students, Stress and University Services", The College Student-Affairs Journal, cilt 27, say1 1, 2007.

Proctor, Carmel - Linley, P. Alex, Cross-Cultural Advancements in Positive Psychology, Springer, 2014.

Raffety, Brian D. - Smith, Ronald E. - Ptaceki J. T., "Facilitating and Debilitating Trait Anxiety, Situational Anxiety, and Coping with an Anticipated Stressor: A Process Analysis", Journal of Personality and Social Psychology, cilt 72, say1 4, 1997, (https://doi.org/10.1037/0022-3514.72.4.892).

Rankin, James A. - Paisley, Courtney A. - Mulla, Mazheruddin M. - Tomeny, Theodore S., "Unmet Social Support Needs Among College Students: Relations Between Social Support Discrepancy and Depressive and Anxiety Symptoms", Journal of Counseling Psychology, cilt 65, say1 4, 2018, (http://doi.org: 10.1037/ cou0000269).

Romero, Daniel H. - Riggs, Shelley A. - Ruggero, Camilo, "Coping, Family Social Support, and Psychological Symptoms Among Student Veterans", Journal of Counseling Psychology, cilt 62, say1 2, 2015, (http://doi.org/: 10.1037/ cou0000061).

Rook, Karen S., "Social Support Versus Companionship: Effects on Life Stress, Loneliness, And Evaluations by Others", Journal of Personality and Social Psychology, cilt 52, say1 6, 1987, (https://doi.org/10.1037/0022-3514.52.6.1132).

Saygın, Yeliz, "Üniversite Öğrencilerinin Sosyal Destek, Benlik Saygısı ve Öznel İyi Oluş Düzeylerinin İncelenmesi” (Yayımlanmamış Yüksek Lisans Tezi), Selçuk Üniversitesi, 2008.

Smith, Martin M. - Saklofske, Donald H. - Yan, Gonggu - Sherry, Simon B., "Does Perfectionism Predict Depression, Anxiety, Stress, and Life Satisfaction After Controlling for Neuroticism?”, Journal of Individual, cilt 38, say1 2, 2017, (http://doi.org/:10.1027/1614-0001/a000223).

Song, Juyeon - Bong, Mimi - Lee, Kyehyoung - Kim, Sung-il, "Longitudinal Investigation into The Role of Perceived Social Support in Adolescents' Academic Motivation and Achievement", Journal of Educational Psychology, cilt 107, say1 3, 2015, (http://doi.org/:10.1037/edu0000016).

Szabo, Agnes - Ward, Colleen - Jose, Paul E., "Uprooting Stress, Coping, and Anxiety: A Longitudinal Study of International Students", International Journal of Stress Management, cilt 23, say1 2, 2016, (http://doi.org/:10.1037/a0039771). 
Şahin, Gülin Nur, "Üniversite Öğrencilerinin Kendini Açma, Öznel İyi Oluş ve Algıladıkları Sosyal Destek Düzeylerinin Karşılaştırılması”, (Yayımlanmamış Yüksek Lisans Tezi), Dokuz Eylül Üniversitesi, İzmir, 2011.

Şahin, Nesrin Hisli - Durak, Ayşegül, "Stresle Başa Çıkma Tarzları Ölçeği: Üniversite Öğrencileri İçin Uyarlanması", Türk Psikoloji Dergisi, cilt 10, say1 34, 1995.

Taylor, Shelley E., "Social support: A review", H. S. Friedman içinde, The Oxford Handbook of Health Psychology, Newyork, Oxford University Press, 2011.

Tognoli, J., "Leaving Home", Journal of College Student Psychotherapy, cilt 18, say1 1, 2003, (http://doi.org/:10.1300/J035v18n01_04).

Tompkins, Kelley A. - Brecht, Kierra - Tucker, Brock - Neander, Lucia L. Swift, Joshua K., "Who Matters Most? The Contribution of Faculty, Student-Peers, and Outside Support in Predicting Graduate Student Satisfaction", Training and Education in Professional Psychology, cilt 10, say1 2, 2016, (http://doi.org/: 10.1037/tep0000115).

Ulusoy, Mustafa - Sahin, Nesrin Hisli - Erkmen, Hüsnü, "Turkish Version of The Beck Anxiety Inventory", Journal of Cognitive Psychotherapy, cilt 12, 1988.

Uslu, Mustafa - Girgin, Çağla, "The Effects of Residential Conditions on The Problem Solving Skills Of University Students", Procedia Social and Behavioral Sciences, cilt 2, say1 2, 2010, (http://doi.org/:10.1016/j.sbspro.2010.03.459).

Utsey, Shown O. - Ponterotto, Joseph G. - Reynolds, Amy L. - Cancelli, Anthony A., "Racial Discrimination, Coping, Life Satisfaction, and Self-Esteem Among African Americans", Journal of Counseling and Development, cilt 78, say1 1, 2000, (https://doi.org/10.1002/j.1556-6676.2000.tb02562.x).

Utz, Sonja - Breuer, Johannes, "The Relationship Between Use of Social Network Sites, Online Social Support, and Well-Being", Journal of Media Psychology, cilt 29, say1 3, 2017, (hhtp://doi.org/: 10.1027/1864-1105/a000222).

Ülev, Esra, "Üniversite Öğrencilerinde Bilinçli Farkındalık Düzeyi İle Stresle Başa Çıkma Tarzının Depresyon, Kaygı ve Stres Belirtileriyle İlişkisi”, (Yayımlanmamış Yüksek Lisans Tezi), Hacettepe Üniversitesi, Ankara, 2014.

Weigold, Ingrid K. - Robitscheck, Christine, "Agentic Personality Characteristics and Coping: Their Relation to Trait Anxiety in College Students", American Journal of Orthopsychiatry, cilt 81, say1 2, 2011, (http://doi.org/:10.1111/ j.1939-0025.2011.01094.x). 
Ye, Shengquan - Yu, Lu - Li, in Kit, "A Cross-Lagged Model of Self-Esteem And Life Satisfaction: Gender Differences Among Chinese University Students", Personality and Individual Differences, cilt 52, say1 4, 2012, (https://doi. org/10.1016/j.paid.2011.11.018).

Zimet, Gregory D. - Dahlem, Nancy W. - Zimet, Sara G. - Farley, Gordon K., "The Multidimensional Scale of Perceived Social Support", Journal of Personality Assessment, cilt 52, say1 1, 1988, (http://doi.org/:10.1207/s15327). 